\title{
Polityka edukacyjna Turcji wobec mniejszości religijnych i językowych
}

Streszczenie: Autor wskazuje, że w Turcji asymilacyjną, ultranacjonalistyczną politykę edukacyjną wobec mniejszości religijnych i etnicznych determinuje szereg czynników, m.in.: restrykcyjne interpretowanie przez Turcję postanowień Traktatu z Lozanny z 1923 roku, tj. uznanie wyłącznie za mniejszości religijne wspólnot należących do Kościoła obrządku greckiego i ormiańskiego oraz Żydów, z wyłączeniem jakichkolwiek muzułmańskich mniejszości religijnych; specyficznie rozumiana zasada laickości państwa, nakładająca na szkoły obowiązek prowadzenia lekcji „kultury religijnej i etyki”, które w praktyce sprowadzają się do nauki islamu obrządku sunnickiego i budzą protest alawitów; konstytucyjna zasada, zgodnie z którą w placówkach kształcenia i nauczania obywatele tureccy mogą być nauczani jedynie języka tureckiego jako języka ojczystego, skutkiem czego tylko tzw. mniejszości uznane w Traktacie z Lozanny mają prawo zakładania szkół prywatnych z ojczystym językiem nauczania, podczas gdy mniejszości językowe muzułmańskie mają tylko prawo organizowania w weekendy i w czasie wakacji lekcji „różnych języków i dialektów używanych przez obywateli tureckich w życiu rodzinnym". Tak więc, np. Kurdowie stanowiący około 15\% ludności Turcji nie mają możliwości kultywowania swojego języka. Autor wymienia przykłady pozytywnych zmian władz tureckich w stosunku do mniejszości językowych i religijnych, upatrując ich źródeł w dążeniu Turcji do członkostwa w Unii Europejskiej oraz w tendencji Turcji do doceniania wieloetniczności i wielokulturowości imperium osmańskiego.

Słowa kluczowe: mniejszości religijne i językowe, Traktat z Lozanny, polityka edukacyjna, asymilacja

W Turcji do niedawna obowiązywała konstytucja narzucona przez reżym wojskowy w 1982 roku. Jako kraj aspirujący do członkostwa w Unii Europejskiej Turcja wprowadziła do konstytucji szereg modyfikacji oraz zobowiązała się do reformy kodeksu karnego. Jednak represyjna, dyskryminacyjna i ultranacjonalistyczna polityka Turcji w stosunku do mniejszości religijnych i lingwistycznych prowadzona po upadku Imperium Osmańskiego - w kraju, 
który ma zdecydowanie wielokulturową strukturę demograficzną - nadal zagraża zachowaniu przez nie swej tożsamości etnicznej, lingwistycznej, kulturowej i religijnej.

Traktat pokojowy z Lozanny jest aktem konstytutywnym Turcji nowożytnej. Zawarty 24 lipca 1923 roku (wszedł w życie 30 sierpnia 1924 roku) między przedstawicielami Wielkiej Brytanii, Francji, Włoch, Japonii, Grecji, Rumunii, Serbii i Turcji zakończył wojnę grecko-turecką i ustanowił ramy prawne dla Turcji, która była już wtedy republiką, a Mustafa Kemal Atatürk jej pierwszym prezydentem.

W artykule 37 Traktatu z Lozanny Turcja zobowiązała się do uznania postanowień traktatu międzynarodowego na równi z fundamentalnymi ustawami, takimi jak konstytucja; państwo uznawało nadrzędność traktatu w stosunku do wszelkich innych krajowych aktów prawnych lub „działań oficjalnych" rządu. Artykuł 39 proklamował zasadę niedyskryminacji ze względu na rasę, religię i język. Tenże artykuł przewidywał całkowitą wolność w posługiwaniu się językiem innym niż turecki (Traité de Paix, 1923).

Władze tureckie, prowadząc politykę asymilacji, postanowienia Traktatu z Lozanny interpretowały restryktywnie, uznając wyłącznie mniejszości religijne należące do Kościoła obrządku greckiego i ormiańskiego oraz Żydów. Kryterium religijne stało się wyłączną podstawą do uznania danej grupy za mniejszość. Grupy należące do różnych Kościołów orientalnych, np. Chaldejczycy, wyznawcy Asyryjskiego Kościoła Wschodniego (nestorianie) i Chaldejskiego Kościoła Katolickiego, nie są uznawane za mniejszości religijne. Wyznawcom Kościoła protestanckiego czy Kościoła katolickiego również nie przysługuje status uznanej mniejszości religijnej.

Naród turecki jest definiowany na podstawie dwóch nierozłącznych kryteriów: przynależności do islamu (domniemanej lub realnej) i do tureckości (narzuconej lub dobrowolnej), żadna grupa wyznająca islam nie jest uznawana za mniejszość. Obywatele tureccy Kurdowie, Arabowie i alawici (wspólnota wyznaniowa składająca się zarówno z Kurdów, jak i Turków) jako muzułmanie są uznawani za Turków, i vice versa, jako Turcy są muzułmanami (Hamit, 2005).

Rząd turecki sprzeciwia się przyjęciu innej definicji pojęcia „mniejszość” niż tej, którą wywodzi z Traktatu z Lozanny, argumentując, że w prawie międzynarodowym nie ma ścisłych i obowiązujących definicji pojęcia „mniejszość” i że praktyka oficjalnego uznania części populacji za mniejszość narodową, etniczną lub inną różni się w poszczególnych państwach i należy do ich kompetencji (Rapport de l'ECRI sur la Turquie, 2016). Przy tym, co 
ciekawe, powołuje się m.in. na wyrok Europejskiego Trybunału Praw Człowieka w sprawie Gorzelik i inni przeciwko Polsce ${ }^{1}$. Sprzeciwiając się zaliczaniu do mniejszości np. Romów i Kurdów będących obywatelami tureckimi, podkreśla niedyskryminacyjny charakter artykułu 10. Konstytucji Republiki Tureckiej (2013, s. 57)2.

Powodem wyrażenia ww. stanowiska rządu tureckiego stał się kolejny Raport Komisji Europejskiej Przeciwko Rasizmowi i Nietolerancji (ECRI) z 2016 roku w sprawie Turcji, w którym przyjęto następującą definicję „grup mniejszościowych: „Uznaje się za »grupy mniejszościowe« wszystkie grupy społeczeństwa tureckiego mające odrębną religię, pochodzenie narodowe lub etniczne, język lub kolor skóry, niezależnie od tego czy są uznane lub nieuznane za mniejszości przez Traktat z Lozanny" (Rapport de l'ECRI sur la Turquie, s. 34, przekł. autora).

Należy zaznaczyć, że Turcja nie podpisała dotychczas Konwencji ramowej o ochronie mniejszości narodowych (1995), Konwencji UNESCO w sprawie zwalczania dyskryminacji w dziedzinie oświaty (1960), Europejskiej karty języków regionalnych lub mniejszościowych (1992) oraz Protokołu nr 12 (wprowadzającego całkowity zakaz dyskryminacji) Europejskiej konwencji praw człowieka i podstawowych wolności (1953), pomimo krytyki Komisji Europejskiej i instancji Rady Europy kierowanej do rządu tureckiego.

Na początku 2016 roku populacja Turcji wynosiła 78 mln mieszkańców, w większości sunnitów. Brak oficjalnych danych dotyczących składu ludności uniemożliwia ścisłe ustalenie liczebności grup etnicznych czy wspólnot religijnych, dlatego dane szacunkowe pochodzące z różnych źródeł są rozbieżne.

Szacuje się, że Kurdowie mogą stanowić od 10 do $20 \%$ ludności, pozostałe zaś mniejszości etniczne od 7 do 12\%; Romowie od 500 tys. do $5 \mathrm{mln}$, Ormianie od 40 do 90 tys., Grecy od 3 do 4 tys., Żydzi - 20 tys. Według władz

1 Spór o istnienie społeczności Ślązaków, po wyczerpaniu drogi w instancjach krajowych, zakończył się dopiero wyrokiem Europejskiego Trybunału Praw Człowieka w sprawie Gorzelik i inni przeciwko Polsce. Trybunał nie dopatrzył się w działaniach sądów polskich, odmawiających zarejestrowania stowarzyszenia pod nazwą Związek Ludności Narodowości Śląskiej (do celów statutowych związku miały należeć m.in. rozbudzanie i ugruntowywanie solidarności narodowej Ślązaków oraz ochrona praw etnicznych narodowości śląskiej), naruszenia art. 11 Konwencji o ochronie praw człowieka i podstawowych wolności dotyczącego wolności zgromadzeń i prawa do swobodnego stowarzyszania się.

2 „Wszyscy są równi wobec prawa bez względu na język, rasę, kolor skóry, płeć, poglądy polityczne i przekonania filozoficzne, religię, wyznanie, bądź inne względy”. 
tureckich w 2016 roku, ponad 2,7 mln uchodźców syryjskich i około 300 tys. z Iraku przebywało w Turcji.

Inne grupy mniejszościowe to: Arabowie, Azerowie, Kabardyjczycy, Persowie, Bułgarzy (Pomacy), Tatarzy krymscy, Gruzini, Kazachowie, Karakałpacy, Bośniacy, Serbowie, Uzbecy, Czerkiesi i in.

Złożoność i paradoksy polityki tureckiej w stosunku do mniejszości religijnych pozostają m.in. w związku z proklamowaną zasadą laickości państwa. Ta laickość nie uwzględnia różnorodności tureckich wspólnot muzułmańskich, w szczególności alawickiej3. Wyznawcy alawizmu stanowią od 10\% do $40 \%$ populacji kraju.

Turcja jest pierwszym i jedynym państwem laickim w świecie islamu. Czerpiąc inspirację z ideologii Oświecenia i Rewolucji Francuskiej, zarówno Francja, jak i Turcja wprowadziły laickość do swego ustawodawstwa i konstytucji: Francja na początku XX wieku, Turcja w okresie międzywojennym za rządów Kemala Paşy. Realizacji zasad laickości - w warunkach historycznych, specyficznych dla każdego kraju - towarzyszyły konflikty dotyczące: miejsca religii dominującej w państwie i społeczeństwie, istnienia i finansowania szkolnictwa wyznaniowego, laickości publicznego systemu szkolnego i in.

Generalnie można uznać, że laickość w Turcji najczęściej była wprowadzana lub ponownie ustanawiana siłą i w wyniku wielokrotnych interwencji wojska. Tymczasem religia nie dopuszczała sekularyzacji, a społeczeństwo nie było przygotowane do reform, z wyjątkiem części mieszkańców miast, funkcjonariuszy, nauczycieli i wojskowych. Nic więc dziwnego, że ten brak szerokiej bazy społecznej dla reform zaowocował kontestacją, oporem i rewindykacjami oraz koniecznością rewidowana swojego stanowiska wobec religii przez partie rządzące. Działania administracyjne i ustawodawcze sprzyjające islamowi nasiliły się zwłaszcza w okresie rządów Turguta Özala (1989-1993). W latach 1983-1997 stale powiększała się liczba szkół średnich kształcących personel religijny, szkół koranicznych oraz zwiększał się budżet Dyrektoriatu ds. Religii.

Najbardziej znaczącą przeszkodą w laicyzacji szkolnictwa było wprowadzenie w 1982 roku obowiązkowych lekcji „kultury religijnej i wiedzy o etyce” według zasad sunnickich w szkolnictwie podstawowym i średnim. Dokonało się połączenie islamu i oficjalnej autorytarnej ideologii, bardzo wyraźne w podręcznikach do lekcji „kultura religijna i etyka”, które świadczą o próbie

3 Ugrupowanie religijne wywodzące się z muzułmańskiego ruchu szyickiego. Drugie największe wyznanie w Turcji, jeśli chodzi o liczbę wiernych. 
pogodzenia islamu i kemalistowskiej ideologii. Z tej ideologii, po zamachu stanu w 1980 roku, usunięto kulturowy aspekt reformatorski, sprowadzając ją do autorytaryzmu politycznego i społecznego. Wspomniane podręczniki w znacznej mierze są poświęcone refleksjom Atatürka o niezbędności religii w każdym społeczeństwie, a oficjalny laicyzm jest odtąd uzasadniany wersetami Koranu (Üstel, 2006).

Konstytucja Republiki Tureckiej stanowi: „Edukacja w zakresie religii i etyki odbywa się pod nadzorem i kontrolą państwa. Nauczanie kultury religijnej i wychowanie moralne znajduje się w obowiązkowym programie dla szkół podstawowych i średnich. Uczęszczanie na inne zajęcia z religii jest dobrowolne, a w przypadku nieletnich pozostawione życzeniu ich opiekunów prawnych" (Konstytucja Republiki Tureckiej, 2013, Art. 24, s. 69).

Programy „kultury religijnej i wiedzy o etyce” są ustalane i kontrolowane przez Ministerstwo Edukacji, a podręczniki wydawane przez wyspecjalizowane wydawnictwa pozostające pod nadzorem urzędników ministerstwa (Aydin i Manço, 1998; Duman, 2004). Dyrektoriat ds. Religijnych, podlegający premierowi, sprawuje nadzór nad wszystkimi meczetami, mianuje imamów i muezinów, nadzorując ich przygotowanie w szkołach kaznodziejów i na fakultetach teologii, kontroluje dzieła zawierające naukę islamu, podręczniki moralności religijnej etc. (Burdy i Marcou, 1995).

W założeniu programy „kultury religijnej i wiedzy o etyce” powinny być zbliżone do historii porównawczej religii oraz edukacji obywatelskiej, z dominantą zasad religii i moralności islamskiej. W praktyce stają się lekcjami religii muzułmańskiej obrządku sunnickiego. Dzieci alawitów muszą w nich uczestniczyć. Tylko chrześcijanie i Żydzi mogą być zwolnieni z tych lekcji, pod warunkiem złożenia odpowiedniego oświadczenia (ujawnienia swego wyznania). Napływają więc skargi alawitów do Europejskiego Trybunału Praw Człowieka w sprawie obowiązkowych lekcji „kultury religijnej i wiedzy o etyce", które nie uwzględniają zasad alawizmu. Skargi alawitów dotyczą również nierównego traktowania miejsc ich kultu cemevis, które nie są oficjalnie uznane przez państwo, w odróżnieniu od meczetów, synagog i kościołów. Alawici krytycznie też oceniają przedstawianie ich religii w podręcznikach.

Rozpatrując skargi alawitów, Europejski Trybunał Praw Człowieka uznał w 2016 roku, że w Turcji brak procedur uznawania wyznań religijnych; stosunek władz do wspólnoty alawitów, jej praktyk religijnych i miejsc modlitwy był niezgodny z obowiązkiem państwa zachowania neutralności oraz prawem wspólnoty religijnej do autonomicznego istnienia. Alawici mieli wiele pro- 
blemów dotyczących nie tylko życia religijnego ich wspólnoty, ale również prawa rodziców, których dzieci uczestniczą w przymusowych lekcjach „kultury religijnej i etyki" w szkole podstawowej i średniej. Trybunał stwierdził, że rodzice wyznania alawickiego mogli w sposób uprawniony uważać, że rozwiązania odnoszące się do nauczania w tej sferze mogły rodzić konflikt lojalności ich dzieci między szkołą i ich własnymi wartościami. Trybunał stwierdził w szczególności, że system edukacyjny w Turcji nie był przygotowany do zapewnienia poszanowania przekonań tych rodziców. Trybunał uznał również, że metoda obliczania stopni dla testu przyjęć do szkolnictwa średniego dyskryminowała uczniów zwolnionych z lekcji „kultury religijnej i etyki" (İzzettin Doğan i inni przeciwko Turcji, 2016).

Często „lekcjom kultury religijnej” towarzyszą praktyki kultowe nieprzewidziane w programie, np. ablucje, modlitwa i uczęszczanie do meczetów, które wykraczają daleko poza „wprowadzenie do kultury religijnej” (Institut Kurde de Paris, 2009). Również obowiązek recytowania codziennie przysięgi, narzucony wszystkim uczniom, nie wyłączając szkół prywatnych, budzi sprzeciw. Wprawdzie władze tureckie podkreślają, że ostatnia fraza przysięgi "ne mutlu Türkum diyene”, ,jakże szczęśliwy jest ten, kto uważa się za Turka”, nie ma konotacji etnicznej, lingwistycznej lub religijnej i służy wzmocnieniu poczucia przynależności do Republiki Tureckiej u wszystkich dzieci niezależnie od ich pochodzenia, tym niemniej niektóre grupy mniejszościowe wskazują na niejednoznaczność pojęcia „tożsamość turecka”, co znajduje wyraz w praktyce stosowania prawa.

Jeśli chodzi o sytuację mniejszości religijnych niemuzułmańskich, to jest ona niesatysfakcjonująca $\mathrm{z}$ punktu widzenia międzynarodowych norm prawnych i skutkuje emigracją ich przedstawicieli z Turcji.

I tak, Kościoły obrządku greckiego i ormiańskiego oraz Kościół katolicki i protestancki nie mają pełnej osobowości prawnej, co stwarza wspólnotom wyznaniowym poważne problemy. Jedyną formą umożliwiającą wspólnotom religijnym prowadzenie dzieł kulturalnych czy społecznych oraz stanie się właścicielami nieruchomości są fundacje, na czele których stać musi zawsze obywatel turecki.

Jednak fundacje napotykają na wiele przeszkód natury organizacyjnej ze strony sądów i Dyrekcji Generalnej ds. Fundacji. Komisja Wenecka uznała, że dopóki wspólnoty religijne będą zmuszone tworzyć fundacje i nie będą miały pełnej osobowości prawnej, dopóty może mieć miejsce pogwałcenie prawa do własności zagwarantowane w Protokole Dodatkowym Europejskiej Konwencji Praw Człowieka (Raport de l'ECRI sur la Turquie, 2011, s. 37). 
Kwestia języków mniejszościowych. Z kilkudziesięciu języków, którymi posługują się mieszkańcy Turcji, większość należy do rodziny ałtajskiej i indoeuropejskiej. Ponad 78\% ludności posługuje się językiem tureckim.

Art. 42 Konstytucji tureckiej stanowi: „W placówkach kształcenia i nauczania obywatele tureccy mogą być nauczani jedynie języka tureckiego jako języka ojczystego. Nauczanie języków obcych w placówkach kształcenia i nauczania oraz edukacja w szkołach, gdzie językiem wykładowym jest język obcy, odbywa się na zasadach określonych ustawą. Respektowane są postanowienia umów międzynarodowych" (Konstytucja Republiki Tureckiej, 2013, Art. 42). W praktyce oznacza to, że tylko mniejszości uznane przez Traktat z Lozanny, a więc niemuzułmańskie, mogą zakładać szkoły prywatne, w których językiem nauczania jest ich język macierzysty.

Większość tych szkół należy do uznanych mniejszości chrześcijańskich. Formalnym dyrektorem jest przedstawiciel mniejszości, lecz uprawnienia decyzyjne posiada wicedyrektor muzułmanin wyznaczony przez władze państwowe. W szkołach tych istnieją dwie kategorie nauczycieli: nauczyciele uczący języka tureckiego opłacani przez państwo i nauczyciele języka mniejszościowego wynagradzani przez wspólnotę religijną. Szkoły te nie korzystają $\mathrm{z}$ żadnych subwencji państwowych i napotykają na poważne trudności o charakterze administracyjnym, jak również związane z rekrutacją uczniów. Nie zezwala się na uczęszczanie do szkoły prowadzonej przez uznaną mniejszość wyznaniową dzieciom członków należących do mniejszości niemuzułmańskiej, lecz nie mających obywatelstwa tureckiego.

Wspólnota grecka w Turcji jest niewielka na skutek trudnych relacji historycznych między krajami i nierozwiązanego konfliktu cypryjskiego. Mała liczba dzieci utrudnia tej wspólnocie tworzenie szkół prywatnych. Niedostatek podręczników w języku greckim i problemy ze znalezieniem nauczycieli sprawia, że dzieci należące do tej mniejszości mają ograniczony dostęp do nauki języka ojczystego. Przygotowanie kleru dla wspólnoty greckiej również rodzi poważne problemy, bowiem ustawodawstwo tureckie wymaga, aby duchowieństwo mniejszości wyznaniowej posiadało obywatelstwo tureckie.

Wspólnota ormiańska jest najliczniejszą wspólnotą chrześcijańską w Turcji. Jej sytuacja jest podobna pod wieloma względami do sytuacji mniejszości greckiej, a tragiczne wydarzenia z 1915 roku, których ofiarą stali się Ormianie, rzutują na ich obecne relacje z Turkami. W szkołach prywatnych występują problemy z podręcznikami w języku ormiańskim i brakiem nauczycieli mających przygotowanie do nauczania języka ojczystego. Stale zmniejsza się liczba uczniów uczęszczających do szkół prywatnych. Niektó- 
rzy rodzice rezygnują z posyłania swych dzieci do tych szkół, obawiając się zagrożeń dla dzieci i ich samych ze strony nieprzyjaznego nieraz środowiska.

W 2008 roku Ministerstwo Edukacji zleciło wszystkim publicznym szkołom podstawowym wykorzystanie DVD, których treść antyormiańska była w jawnej sprzeczności z celem, jakim jest budowanie społeczeństwa otwartego i tolerancyjnego. Nie był to pierwszy przypadek rozpowszechniania w szkołach tego typu treści. Na skutek protestów części opinii publicznej Ministerstwo Edukacji poleciło wycofanie DVD. W tym kontekście środowiska ormiańskie zwróciły uwagę na wsparcie finansowe, jakie Turcja, jako kraj aspirujący do członkostwa w Unii Europejskiej, otrzymała od tej organizacji w latach 1995-1999 i 2003-2009 dwukrotnie 120 mln euro na cele szkolnictwa i że od 2003 roku Turcja mogła uczestniczyć w programach Socrates, Leonardo da Vinci i Młodzież (Collectif VAN, 2009).

Stosunek państwa tureckiego do wspólnoty żydowskiej, według jej przedstawicieli, jest poprawny. Po rozpadzie Imperium Osmańskiego tereny rewindykowane przez Żydów znalazły się poza granicami Turcji, w przeciwieństwie do roszczeń terytorialnych Greków i Ormian. Nie bez znaczenia są też ścisłe kontakty obydwu państw w dziedzinie militarnej. Jednak opinia publiczna generalnie nie jest przychylna Żydom, granice zaś między krytyką stanowiska i działań państwa Izrael a stygmatyzacją wspólnoty lub religii żydowskiej zacierają się nieraz w oficjalnych wypowiedziach polityków.

Mniejszości muzułmańskie, które w Traktacie z Lozanny są pominięte, nie mają prawa prowadzenia szkół prywatnych, w których językiem nauczania byłby język mniejszościowy. Jednak pod wpływem instytucji międzynarodowych władze tureckie poczyniły na ich rzecz pewne ustępstwa. Ograniczone możliwości nauki języków mniejszościowych stworzyło Rozporzqdzenie w sprawie nauczania $w$ różnych językach i dialektach tradycyjnie używanych przez obywateli tureckich $w$ życiu codziennym z 2002 roku. W rozporządzeniu żaden język mniejszościowy nie jest wymieniony, nawet kurdyjski, mimo że językiem tym posługuje się ponad 15 mln mieszkańców Turcji i większość rewindykacji lingwistycznych jest artykułowanych przez Kurdów. Słowem, unika się posługiwania w akcie prawnym pojęciem "języki mniejszościowe” - są one traktowane jako „dialekty” lub „języki różne” używane tradycyjnie przez „obywateli tureckich” w życiu prywatnym. Wymienione rozporządzenie wprawdzie umożliwia zakładanie szkół prywatnych oferujących naukę tych języków, lecz wyłącznie w weekendy i w okresie letnich wakacji. Ograniczenia te nie sprzyjają frekwencji uczniów. Poza tym, na skutek nieustających konfliktów Kurdów z rządem, poddawanych represjom i przesiedleniom 
(około 1 mln przesiedlonych - stan z 2006 roku), szkoły te mają efemeryczny charakter.

Wobec braku danych etnicznych nie ma statystyk dotyczących wskaźników skolaryzacji dzieci należących do mniejszości etnicznych lub religijnych. Jednak spis ludności ukazuje znaczne różnice w skolaryzacji według regionów. Wskaźniki dotyczące południowo-wschodniej i środkowo-wschodniej części kraju, zamieszkanych głównie przez Kurdów, są poniżej średniej krajowej. Również skolaryzacja dzieci romskich jest niezadawalająca, o czym świadczy program wyrównawczy tureckiej Rady Edukacji z 2008 roku, przeznaczony przede wszystkim dla dzieci romskich w wieku 10-14 lat, które nigdy nie uczęszczały do szkoły lub przerwały naukę.

Kurdowie i Romowie są grupami najbardziej narażonymi na marginalizację w dostępie do edukacji, albowiem doznają przymusowych przesiedleń, które utrudniają dzieciom dostęp do systemu szkolnego. Deportacje Kurdów związane są z niszczeniem ich wiosek. Według raportu Minority Rights ponad 30\% rodzin kurdyjskich deportowanych do Stambułu z Diyarbakir nie posyła swych dzieci do szkół, przede wszystkim ze względu na brak środków materialnych. Romowie są narażeni na likwidowanie ich dzielnic i deportacje pod pretekstem projektów „urbanistycznych”. Jako przykład można wymienić zlikwidowanie historycznej dzielnicy romskiej Sulukule w Istambule i przymusowe wysiedlenie jej mieszkańców. Turcja nie ma globalnej strategii promowania praw Romów i nie uczestniczy w Dekadzie na rzecz Romów w Europie.

Ponieważ wiele dzieci wywodzących się z mniejszości kurdyjskiej i innych grup mniejszościowych nie ma opanowanego w dostatecznym stopniu języka tureckiego, który jest językiem nauczania w szkołach publicznych, występuje dyskryminacja strukturalna. Aby te dzieci mogły pomyślnie ukończyć szkołę podstawową, a następnie średnią, konieczne jest zwiększenie dostępu do edukacji przedszkolnej, ta zaś w Turcji nie jest obowiązkowa, a rodzice muszą partycypować w jej kosztach. Tylko w niektórych miastach w szkołach podstawowych są prowadzone bezpłatne zajęcia przedszkolne. Ma to bezpośredni wpływ na skolaryzację dzieci, przede wszystkim z mniejszości defaworyzowanych. W 2012 roku tylko 5\% dzieci w wieku 3 lat i 19\% w wieku 4 lat uczęszczało do przedszkoli w Turcji, podczas gdy średnia dla krajów OECD wynosiła 70\% (OECD, 2014).

Perspektywa członkostwa Turcji w Unii Europejskiej sprawiła, że w ostatnich latach można zaobserwować pewne pozytywne przejawy ewolucji w polityce władz tureckich wobec mniejszości religijnych i językowych. 
I tak od 2012 roku zezwala się na prowadzenie w szkołach publicznych fakultatywnej nauki języka kurdyjskiego, abchaskiego, adygejskiego, lazyjskiego i gruzińskiego, na tej samej zasadzie jak języki obce, takie jak angielski, francuski, niemiecki; w uniwersytetach powstały instytuty literatury i języków: kurmandżi (głównego dialektu kurdyjskiego), ormiańskiego, gruzińskiego, syrjackiego ${ }^{4}$ i zazaki ${ }^{5}$. Jako przykład są wymieniane uniwersytety w Tunceli i Siirt. W 2014 roku w Uniwersytecie Artuklu w Mardin ${ }^{6}$ powstała Biblioteka Kurdologiczna gromadząca manuskrypty z kraju i z zagranicy. Z inicjatywy Tureckiego Towarzystwa Językowego w 2014 roku wydano słowniki dwujęzyczne: turecko-kurdyjski i kurdyjsko-turecki, zawierające odpowiednio ponad 12 i 13 tys. haseł. W 2013 roku, po 49 latach, zezwolono Kurdom na przywracanie oryginalnych, dawnych nazw ich miejscowościom.

Na uwagę zasługuje kwestia imion kurdyjskich. Przez długi czas były one przedmiotem zakazów. W 2003 roku Ministerstwo Spraw Wewnętrznych zezwoliło wprawdzie nadawanie imion kurdyjskich, lecz tylko tych, które są tworzone w alfabecie tureckim. Tymczasem w alfabecie tureckim nie ma liter [q], [w] i [x], niezbędnych do transkrypcji języka kurdyjskiego (kurmandżi). Dopiero w 2014 roku z tureckiego Kodeksu karnego usunięto sankcje za używanie wymienionych liter. Jako zapowiedź pozytywnych działań można też uznać przyjęty w 2016 roku Dokument strategiczny na rzecz integracji społecznej obywateli romskich, obejmujący takie dziedziny, jak: edukacja, zatrudnienie, zdrowie, mieszkalnictwo i in. Postępuje autonomizacja Romów, którzy tworzą liczne stowarzyszenia i mają swego deputowanego w Parlamencie. Poza tym, przedstawiciele państwa tureckiego zaczęli okazywać publicznie bardziej przychylne nastawienie wobec mniejszości. Świadczą o tym: przekazanie przez rząd wyrazów ubolewania wspólnocie ormiańskiej z okazji upamiętnienia tragicznych wydarzeń z 24 kwietnia 1915 roku, określonych jako „nieludzkie”; przesłanie prezydenta republiki z okazji Międzynarodowego Dnia Pamięci o Ofiarach Holokaustu z życzeniami pokoju i szczęścia dla wszystkich Żydów, podkreślające wielowiekową pokojową koegzystencję

4 Syriacki (syryjski) - dialekt wschodnioaramejski z okolic Edessy (obecnie Sanliurfa w Turcji), używany do dziś przez kościoły jakobicki, asyryjski, maronicki i malabarski.

5 Zazaki - język narodowości Zaza używany we wschodniej Anatolii.

6 Tunceli, Siirt, Mardim - miasta w Anatolii.

7 Ormianie określają te wydarzenia mianem ludobójstwa, podobnie jak Rada Europy, Parlament Europejski i wiele państw. Turcja neguje fakt dokonanego ludobójstwa na własnych obywatelach. 
obydwu narodów oraz ich przynależność „do cywilizacji, która traktuje różnorodnośc jako wartość". Od roku 2012 prezydenci republiki wydają obiady z okazji zakończenia corocznego postu dla reprezentantów tureckich wspólnot alawitów (Rapport de l'ECRI sur la Turquie, 2016, s. 21).

Jak zauważa Joanna Bocheńska (2011), źródeł bardziej liberalnego stosunku władz tureckich wobec mniejszości można upatrywać m.in. w „odkrywaniu na nowo" wielokulturowości wieloetnicznego imperium osmańskiego, którą w czasach republiki poddawano krytyce i obarczano winą za rozpad państwa po pierwszej wojnie światowej.

Unia Europejska współistnienie wielu grup kulturowych traktuje jako zjawisko społecznie funkcjonalne, jako określoną wartość, dąży do pozyskania do tej idei społeczeństwa oraz tworzy instytucjonalne warunki i porządek normatywny umożliwiający grupom mniejszościowym zachowanie tożsamości kulturowej. Mniejszości językowe i religijne Turcji pokładają nadzieję na lepszą przyszłość w członkostwie ich kraju w Unii Europejskiej, którą postrzegają jako obszar demokracji i pluralizmu.

\section{Bibliografia}

Aydin, M. Z., Manço, U. 1998. L'enseignement de la religion et de la morale dans le système éducatif turc. Conférence du Centre El Kalima. 28. http:// www.flwi.ugent.be/cie/aydin_manco1.htm (29.02.2017).

Bocheńska, J. 2011. Piękne słowo Anadolu. Znak. 669. http://www.mieiecznik.znak.com.pl/6692011spis-tresci/.

Burdy, J.-P. i Marcou, J. 1995. Laicité/laiklik: introduction. Cahiers d'études sur la Méditerranée orientale et le monde turco-iranien. 19, ss. 5-34.

Collectif VAN (Vigilance Arménienne contre le Négationisme) 2009. UE/ Turquie: des écoliers sous mauvaise influence. Info 10 Mars. http://collectifvan.org (28.02.2017).

Commission européenne contre le racism et l'intolérance 2011. Rapport de l'ECRI sur la Turquie (quatrième cycle de monitoring). Adopté le 10 decembre 2010. Strasbourg: Conseil de l'Europe. www.coe.int/ecri (28.02.2017).

Commission européenne contre le racism et l'intolérance 2016. Rapport de l'ECRI sur la Turquie (cinquième cycle de monitoring). Adopté le 29 juin 2016. Strasbourg: Conseil de l'Europe. www.coe.int/ecri (28.02.2017).

Duman, D. 2004. Laïcité et islamisme en Turquie aujourd'hui. Revue internationale d'éducation de Sèvres. 36, ss. 123-133. 
Hamit, B. 2005. Les minorités en Turquie. Pouvoirs. 4, s. 101.

www.cairn.info/revue-pouvoirs-2005 4page-101.htm (28.02.2017).

Institut Kurde de Paris 2009. Turquie: l'enseignement de la langue kurde "imposible" selon R. Teyyip Erdogan". Bulletin. 3. http:/www.institutkurde. org/publications/bulletins/288.html (2.03.2017).

İzzettin Doğan i inni przeciwko Turcji (wyrok - 26 kwietnia 2016 roku, Wielka Izba, skarga nr 62649/10. Odmowa m.in. umożliwienia alawitom odbywania publicznych uroczystości religijnych zastrzeżonych wytacznie dla sunnitów.

Konstytucja Republiki Tureckiej. 2013. Warszawa: Wydawnictwo Sejmowe. Observations of the turkish governement on ECRI's fifth report on Turkey. 2016. W: Commission européenne contre le racism et l'intolérance. Rapport de l'ECRI sur la Turquie (cinquième cycle de monitoring). Adopté le 29 juin 2016. Strasbourg: Conseil de l'Europe. www.coe.int/ecri (2.03.2017).

OECD 2014. Education at a Glance 2014. OECD Indicators. OECD, s. 317. http://dx.doi.org/10.1787/eag-2014-en (1.03.2017).

Rabczuk, W. 2007. Polityka edukacyjna Unii Europejskiej. Nowe konteksty. Warszawa: IBE.

Traité de Paix, signé à Lausanne le 24 Juillet 1923. www.eurel.info/IMG/pdf/ gr_traite_lausanne.pdf (28.02.2017).

Üstel, F. 2006. Les partis politiques turcs, l'islamisme et la laïcité. Cemoti. 19. http://cemoti.revues.org/document1703.html (29.02. 2017).

\section{Educational policy of Turkey towards religious and language minorities}

Abstract: According to the author, in Turkey, the assimilation, ultranationalist educational policy against religious and ethnic minorities is determined by a number of factors: the restrictive interpretation by Turkish authorities of the provisions of the Treaty of Lausanne, i.e. only some citizens of Turkey belonging to non-Muslim minorities fall within the scope of the term "minority"; a peculiar understanding of the principle of secular state imposing a duty on schools to conduct lessons of "religious culture and ethics", which in practice boils down to the teachings of Sunni Islam. What raises an objection of the religious community of Alawites is the constitutional principle that no language other than Turkish shall be taught as the mother tongue to Turkish citizens at any institution of training or education. The effect is that only the so-called "minorities recognized" by the Treaty of Lausanne have the right to establish private schools educating in the native language, 
while the Muslim minority has only the right to organize at weekends and during school holidays lessons "of different languages and dialects used by Turkish citizens in their family life." Thus, the Kurds, who represent around 15\% of Turkey's population, are unable to cultivate their language. The author cites examples of positive changes of Turkish authorities in relation to linguistic and religious minorities, seeing their source in Turkey's aspirations to the EU membership and in the recent tendency to the appreciation of multi-ethnicity and multiculturalism of the Ottoman Empire.

Keywords: religious and linguistic minorities, diversity, Treaty of Lausanne, educational policy, assimilation 